\title{
A Literatura Oftalmológica e os Arquivos Brasileiros de Oftalmologia como Instrumentos de Educação e Atualização
}

\author{
Rubens Belfort Jr.
}

Há anos atrás o médico recém-formado podia esperar que o conhecimento serviria para vida inteira. Pelo menos para 25 anos. Nos Estados Unidos, algumas especialidades já têm seus títulos de especialista com certificações quase anuais e existe grande pressão para a validade do título de especialista do oftalmologista, hoje com validade de 10 anos, baixar para um período bem menor.

A revolução na tecnologia da informação levou à possibilidade da informação freqüente, rápida e, principalmente, cada vez mais correta. A incorreta não é somente inútil; é perigosa. Como geralmente a informação obtida, é logo utilizada, não se pode correr o risco e a conseqüência da informação falsa levar à conduta errada e resultados piores. Assim, existe a preocupação crescente de textos e informes científicos serem corretos, corretamente apresentados e peer reviewed. Apesar do sistema de validação pelos pares (peer review) não ser perfeito, tem se mostrado eficiente e é o melhor e, provavelmente vai continuar a existir ainda durante muitos anos de maneira semelhante em todas as grandes revistas, tornando as outras, eventualmente, até perigosas.

Também os títulos de artigos e as metodologias empregadas precisam ser mais claras, rígidas e adequadas, permitindo a leitura e interpretação corretas.

Não só o resumo deve ser apresentado de maneira objetiva e conter peças mais importantes mas o próprio estudo, para ser definido como de uma determinada metodologia (como por exemplo "clinical trial"), tem que seguir os critérios de definição. Um bom exemplo é a normatização apresentada na revista "Ophthalmology".

A "oftalmologia baseada em evidências" e a meta-análise já são realidade e o aprendizado de sua interpretação é indispensável, até para combater parte dos excessos, decorrentes do modismo.

Através de home pages como a http://www.supersight.com pode se saber o que vai ser impresso em 2 meses e em futuro próximo é provável que revistas científicas sejam publicadas diariamente, à medida que os artigos recebidos da peer review tenham sido aprovados pela Comissão Editorial. Não há por- que esperar para publicar, atrasando a divulgação de avanços e do conhecimento uma vez que o artigo não vai mais para a gráfica, sendo impresso e finalmente colocado no correio postal. A edição eletrônica significa tempo zero e custo tão baixo que todos os artigos úteis poderão ser publicados, desde que corretos.

Não haverá mais razão para a não publicação de um artigo por razões econômicas ou falta de "espaço" e serão publicados desde que corretos e úteis.

Também as cartas aos autores e editores serão "on line" (em tempo real).

Os Arquivos Brasileiros de Oftalmologia estão à frente nestes avanços, mesmo em relação ao primeiro mundo: mas a utilidade deste modernismo depende dos Oftalmologistas e também suas organizações que devem estimular seu uso.

Desde 1998 os ABO, em sua home page apresentam os abstracts e o índice do número seguinte e os artigos publicados podem ser discutidos "on line" com os autores, pelos leitores.

A partir de outubro de 99, os ABO estão na Web (home page) na íntegra, com consulta instantânea e gratuita. Apenas 300 revistas científicas. Com o tempo, seguramente, muitos preferirão mesmo não receber a versão em papel, com grande economia. Novos problemas e soluções; entre eles a pergunta se a propaganda que subvenciona muitas revistas perderá sua valia? Será esta subvenção também desnecessária??

As citações bibliográficas também mudarão, serão todas "vivas" e, o toque, ao invés de apenas apresentar a referência, mostrará também a sua íntegra e contexto, bem como a dos autores e seus trabalhos, abrindo um sem fim de informações e caminhos.

Em resumo a informação será mais verdadeira, mais rápida, mais completa e mais barata. A dificuldade é que continuará sendo cada vez mais abundante, impossível de ser lida.

A sua relação e integração para uso adequado constituirão como já hoje, o grande desafio para o ser humano, necessitando-se e premiando-se os capazes de discernir o mais exato, útil e adequado para instrumentalizar o avanço da ciência e da medicina. 